\title{
Smallholder family farmers' perceptions, attitudes and choices regarding husbandry practices that influence performance and welfare of lactating dairy calves
}

\author{
Vilmar Fruscalso ${ }^{1,3}$ Gabriela Olmos Antillón ${ }^{2,3}$ Maria José Hötzel ${ }^{3^{*}}$
}

\begin{abstract}
${ }^{1}$ Associação Riograndense de Empreendimentos de Assistência Técnica e Extensão Rural (Emater), Porto Alegre, RS, Brasil.
${ }^{2}$ Department of Animal Environment and Health, Swedish University of Agricultural Sciences, Uppsala, Sweden.

${ }^{3}$ Laboratório de Etologia Aplicada e Bem-Estar Animal, Universidade Federal de Santa Catarina (UFSC), 88034-000, Florianópolis, SC, Brasil. E-mail: maria.j.hotzel@ufsc.br. .Corresponding author.
\end{abstract}

\begin{abstract}
This study aimed to describe the management practices used in dairy farms in the south of Brazil, and to understand farmers perceptions and attitudes regarding these practices. Farms $(n=135)$ located in all 32 of the municipalities in the northern region of Rio Grande do Sul (Alto Uruguai Gaúcho), Brazil were characterized regarding all calf management practices during a farm visit where farms were inspected and farmers interviewed. In a second visit, 25 in depth interviews were done to understand farmers' attitudes and perceptions towards these practices and potential influence on calves'welfare and performance. Management of lactating calves was perceived by most of the interviewees as of marginal importance for dairy activity. In general farmers did not perceive animal welfare as relevant, and most chose management practices mainly based on practical, productive and economic factors. These conclusions are consistent with management practices used by farmers, many of which represent risk factors for low calves'survival, growth and welfare. Seven factors (self-responsibility, economic ambition, technical assistance, family succession, urban experiences, specialization and family commitment) appeared to influence farmers' perceptions, attitudes and choices regarding husbandry practices that affect the welfare and performance of calves, which may be considered when designing programs aiming to improve dairy calf management.

Key words: dairy, lactation, suckling, young cattle.
\end{abstract}

Percepções, atitudes e escolhas de agricultores familiares acerca de práticas de manejo que influenciam o desempenho e o bem-estar de bezerras leiteiras lactentes

RESUMO: Os objetivos deste estudo foram descrever as práticas de manejo usadas em granjas leiteiras no sul do Brasil e compreender as percepções e atitudes dos agricultores acerca destas práticas. Granjas (n=135), localizadas nos 32 municípios do norte do Rio Grande do Sul (Alto Uruguai Gaúcho), foram visitadas e caracterizadas em relação a todas as práticas de manejo da bezerra através de inspeção e entrevistas com os agricultores. Em outro momento, foram realizadas 25 entrevistas em profundidade para entender as percepções e atitudes dos agricultores acerca destas práticas e a sua potencial influência sobre o bem-estar e desempenho das bezerras. A maioria dos entrevistados percebia o manejo da bezerra como de importância marginal para a atividade. Em geral, os agricultores não perceberam o bem-estar animal como relevante e as práticas de manejo adotadas eram baseadas em fatores práticos e econômicos. Estas conclusões são consistentes com as práticas usadas pelos mesmos agricultores, muitas das quais representam fatores de risco para o bem-estar, crescimento e sobrevivência das bezerras. Sete fatores, (autorresponsibilidade, ambição econômica, assistência técnica, sucessão familiar, vivências, especialização e comprometimento familiar) aparentaram influenciar as percepções, atitudes e escolhas dos agricultores acerca das práticas de manejo que afetam o bem-estar e desempenho das bezerras. Estes fatores devem ser considerados na concepção de programas que visam melhorar o manejo da bezerra leiteira.

Palavras-chave: atividade leiteira, bezerra lactente, aleitamento, bovinos jovens.

\section{INTRODUCTION}

Rearing dairy calves born at farm allows a close herd policy, reducing sanitary risks and production costs (TORSEIN et al., 2014). Although decisions regarding the management of young cattle markedly affect dairy farming performance, calf rearing is often neglected by farmers (HÖTZEL et al., 2014a; DOS
SANTOS \& BITTAR, 2015). To improve morbidity and mortality rates and calves' welfare, farmers need to understand how morbidity and mortality are related to daily management practices.

In order to understand the relationship between management and morbimortality, it is necessary to first understand what factors are associated with it. When correct perception precede 
the action, the chances of success in calf rearing increase, since there is a better understanding of effects and consequences of techniques adopted on health and performance of animals. Perception is a complex phenomenon, of multiple definitions, where perceiving is an active process of distinguishing objects in relation to their environment; for the perceiving individual, objects exist only through such distinctions (MATURANA, 2002). Perception occurs from a mental model that is adopted, conscious or unconsciously, that determines the way individuals view and interact with the world (SENGE, 1999). Perception can be shaped by factors linked to the observer, object, or the context in which it occurs. The perception of risk, for example, may result from the association of all these factors within the environment where the farmer lives. Thus, a threat cannot be assessed dissociated from beliefs, perceptions and attitudes of individuals involved. In this sense, attitude consists of a predisposition to respond favorably or unfavorably towards object or behavior (FISHBEIN \& AJZEN, 1972), or an evaluative psychological tendency, which involves taking a position in relation to a given object or behavior (EAGLY \& CHAIKEN, 1995). Perceptions and attitudes may contribute to determine the actions and choices of farmers.

The first objective of this study was to describe management practices used in smallholding family farms in Rio Grande do Sul (RS), south of Brazil. Given that calf management may influence dairy calf welfare and performance, we also aimed to understand farmers' perceptions and attitudes regarding these practices.

\section{MATERIALS AND METHODS}

The present study was characterized as descriptive-exploratory, with a quantitative and a qualitative approach. Dairy farmers $(n=135)$ from all 32 municipalities in the northern region of RS (Alto Uruguai Gaúcho) were invited by Rural Extensionists who work in the municipal offices of Emater RS to participate in a research project that aimed to identify the prevalence and risk factors for morbimortality and growth rates of suckling dairy calves. The region has 6,759 farmers who are commercially engaged in milk production, with 84,000 lactating cows producing 319 million L of milk/year (IGL \& Emater/RS, 2015). Between July and October 2015, the 135 farmers were interviewed and farms inspected using detailed checklists described by BALCÃO et al. (2017) to characterize the production system and practices used. In a follow-up visit between January and May
2016, qualitative data were collected from 25 farmers selected among the 135, using in-depth interviews. Selection of the group for in-depth interviews took into account the type of technical assistance received at the farm and the total number of dry and lactating cows on the farm. Criteria for selection were: a) no more than one farmer/municipality; b) type of technical assistance received; c) herd size. Interviews were similarly distributed according to assistance received, as follows: private/family, cooperative, Emater, multiple (assisted by more than one entity), dairy, and unattended. Within the "Technical Assistance" groups, the 135 participants were distributed by total number of cows (dry + lactating) at the farms (12-17, 18-22, 23-27, 28-35 and 36-80 cows) and chosen randomly. Since the responses had not reached saturation (see below), four further participants were chosen randomly from the group of 135 farms.

Interviews were guided by the following questions: When and why did you start dairy farming? Why and how do you rear the dairy calves? What is the most important aspect for good calf rearing? What is the most important aspect for success in dairy farming? Do you use bull or artificial insemination and what is the difference? Do you have technical assistance, if yes how do you rate it? What are your plans for the future? Farmers were explained the objectives of the study, that the interview would be recorded, and upon verbal agreement of participation he/she was asked to sign the consent form. Interviews were conducted in the farmers' homes and lasted between 40 and 72 minutes.

To ensure consistency, all the interviews were carried out and transcribed by the first author. In qualitative research, it is assumed that the sample size is reached when the responses obtained provided content diversity and richness regarding the issue of the study, which is called saturation ( MINAYO, 2013; CORBIN \& STRAUSS, 2015). In the present study, saturation was achieved with 25 interviews: 13 with the couple, 6 with several members of the family and 6 with just the man. The qualitative analysis and interpretation of the interviews were performed according to the methodology described by CORBIN \& STRAUSS (2015) and MINAYO (2013). Quantitative analysis was used to compare the larger group of 135 and the 25 interviewed farms, either a T-test or Fisher's exact test depending on type of data.

\section{RESULTS AND DISCUSSION}

The main production outcomes and calf management practices of the 25 farms that received 
the follow-up visit and are the scope of this text, and the 135 farms that were part of the study, were in general similar (Tables 1 and 2), confirming the representativeness of the sub-sample selected for the in depth interviews. Many management practices observed, such as lack of calving and neonate care, early cow-calf separation, single housing, low environmental hygiene, and small milk allowances are known as risk factors for pre-weaning calf morbidity and mortality, and reduced calf welfare (VON KEYSERLINGK et al., 2009; HÖTZEL et al., 2014b; COSTA et al., 2016). These results are similar to other surveys involving smallholder dairy farmers of other regions of Brazil (HÖTZEL et al., 2014a; SANTOS \& BITTAR, 2015), which indicated a need for programs seeking to improve calf management that may influence calves' performance, survival and welfare. Farmers and other industry stakeholders should be made aware of the potential repercussions to the dairy industry of consumers' growing concerns towards animal welfare (VON KEYSERLINGK \& HÖTZEL, 2015). Recent research has shown that Brazilians (HÖTZEL et al., 2017), like citizens from other countries (ELLIS et al., 2009; CARDOSO et al., 2016a) are concerned with dairy cattle welfare and reject some of the practices reported to be prevalent in this study.
Perceptions, attitudes, and choices regarding lactating calves' rearing

Below we describe farmers' perceptions, attitudes regarding calf rearing management from birth to weaning and how these relate to the practices they adopt (Tables 1 and 2).

The majority of respondents seemed to have low understanding of the consequences of management strategies for the welfare and performance of calves, as evidenced for example in these statements: "We feed them the same concentrate we use for cows, but they do not grow well" (Man, 43); "If one wants to suck at the other, I just go there and grease their udders" (Man, 65); "If you feed them more than two liters of milk at a time it causes diarrhea" (Man, 44); "When the calves have diarrhea, we give them home made tea" (Woman, 42). These perceptions are consistent with the many inappropriate management, feeding and housing practices observed in calf rearing and listed in tables 1 and 2 . These, in turn, may be related to reduced investments in labor, inputs and facilities, as well as to low cows' productivity. Low investments possibly occur due to lack of awareness of the importance of the calf for the future of milk production.

None of the participants expressed concerns about the welfare of calves; specifically, few farmers

Table 1 - Herd composition, milk production and lactating calves' management in smallholding dairy farms in the north of Grande do Sul, Brazil.

\begin{tabular}{|c|c|c|c|c|}
\hline Variable & Survey $(n=135)$ & Interviews $(\mathrm{n}=25)$ & \multirow{3}{*}{$\begin{array}{c}\text { Chi-squared value } \\
0.13\end{array}$} & \multirow{3}{*}{$\begin{array}{c}P \\
0.72\end{array}$} \\
\hline \multicolumn{3}{|c|}{ - } & & \\
\hline Herd breed predominantly Holstein & 88 & 84 & & \\
\hline Herd size up to 30 milking cows & 79 & 76 & 0.08 & 0.78 \\
\hline Herd with milk production below $15 \mathrm{~L}_{\text {cow }}{ }^{-1}$ day $^{-1}$ & 45 & 44 & 0.01 & 0.91 \\
\hline Average milk production $\left(\mathrm{L} \mathrm{cow}^{-1} \text { day }^{-1}\right)^{1}$ & 16,7 & 16,6 & -0.04 & 0.97 \\
\hline Birth place is clean & 24 & 24 & 0.00 & 0.96 \\
\hline Calving assisted & 75 & 72 & 0.09 & 0.77 \\
\hline Time of newborn with dam $<12 \mathrm{~h}$ & 78 & 80 & 0.06 & 0.80 \\
\hline Colostrum, suckles from dam & 13 & 8 & 0.55 & 0.46 \\
\hline \multicolumn{5}{|l|}{ Colostrum fed artificially, time until first ingestion } \\
\hline$\leq 6 \mathrm{~h}$ & 70 & 68 & 0.03 & 0.87 \\
\hline $6-12 \mathrm{~h}$ & 1.5 & - & $\mathrm{F}^{2}$ & 0.71 \\
\hline Unknown & 29 & 3 & 0.10 & 0.75 \\
\hline \multicolumn{5}{|l|}{ Colostrum. Volume in $24 \mathrm{~h}$} \\
\hline$\leq 4 \mathrm{~L}$ & 31 & 32 & 0.01 & 0.93 \\
\hline$>4$ & 11 & 24 & 3.07 & 0.08 \\
\hline Unknown & 58 & 44 & 1.62 & 0.20 \\
\hline Colostrum quality (immunoglobulins) unknown & 100 & 100 & $\mathrm{~F}^{2}$ & 1.00 \\
\hline Keeps frozen colostrum & 10 & 8 & $\mathrm{~F}^{2}$ & 0.53 \\
\hline
\end{tabular}

${ }^{1}$ T-test. ${ }^{2}$ Fisher Exact Test. 
Table 2 - Lactating calves' management in smallholding dairy farms in the north of Rio Grande do Sul, Brazil.

\begin{tabular}{|c|c|c|c|c|}
\hline Variable & Survey $(n=135)$ & Interviews $(\mathrm{n}=25)$ & \multirow{3}{*}{$\begin{array}{c}\text { Chi-squared value } \\
0.21\end{array}$} & \multirow{2}{*}{$\mathrm{P}$} \\
\hline \multicolumn{3}{|c|}{ 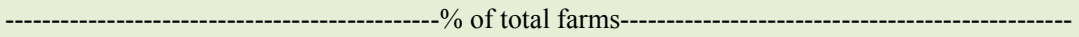 } & & \\
\hline Weaning 60-90 days old & 76 & 88 & & 0.17 \\
\hline Milk fed up to $4.0 \mathrm{~L} \mathrm{day}^{-1}$ & 80 & 76 & 0.21 & 0.65 \\
\hline Provision of concentrate, above $0.5 \mathrm{~kg}$ day $^{-1}$ & 22 & 32 & 0.70 & 0.40 \\
\hline Provision of hay & 59 & 64 & 0.00 & 0.97 \\
\hline \multicolumn{5}{|l|}{ Housing, type } \\
\hline Hutch or indoor pen & 80 & 96 & 0.29 & 0.59 \\
\hline Outdoor pen & 9 & 0 & $\mathrm{~F}^{1}$ & 0.12 \\
\hline Tied & 13 & 4 & $\mathrm{~F}^{1}$ & 0.16 \\
\hline Individual housing & 67 & 68 & 0.02 & 0.90 \\
\hline Housing with good hygiene ${ }^{2}$ & 20 & 20 & 0.00 & 1.00 \\
\hline Housing with good sun incidence ${ }^{3}$ & 33 & 28 & 0.21 & 0.65 \\
\hline Housing with good humidity ${ }^{4}$ & 62 & 80 & 2.93 & 0.09 \\
\hline Disinfects housing at entry & 19 & 12 & 0.75 & 0.39 \\
\hline Dehorns before 90 days of age & 67 & 68 & 0.00 & 0.95 \\
\hline Uses pain control for dehorning & 0 & 0 & $\mathrm{~F}^{1}$ & 1.00 \\
\hline Kills newborn male calves & 23 & 24 & 0.01 & 0.91 \\
\hline
\end{tabular}

${ }^{1}$ Fisher Exact Test. ${ }^{2}$ Good hygiene: clean environment without presence of feces, mud, waste and flies; regular: presence of some mud, feces or residues, covering at most $50 \%$ of the ground (contiguous area) and poor: very dirty environment, presence of mud, feces or waste covering more than $50 \%$ of the ground. ${ }^{3}$ Good sunshine: the animal chooses when it wants to stay in the sun, north-south ridge; regular: shaded by buildings, trees or mountains; small or windowless windows, east-west ridge; poor: no access to solar radiation ${ }^{4}$ Good humidity: dry place; regular: moist place, soil saturated with water, sticky, sticking to shoes; poor: surface water accumulation or mud formation.

mentioned the relevance of issues known to influence calves' quality of life, such as time spent with the dam, social housing, pain, or hunger (VON KEYSERLINGK et al., 2009). Often, when participants suggested practical reasons to support their management choices it was clear that the potential consequences for the animals were not considered: "I leave the calves on a leash in the open, housing is not important" (Man, 53); "We usually do not supervise the births" (Man, 45 years). These examples indicated little concern among farmers about animal welfare when deciding what production systems or management strategies to adopt. As shown by HÖTZEL et al. (2014a), farmers chose management practices that are known to influence animal welfare based exclusively on economic or productive reasons. This seemed true even for some farmers that invested in improving calf's performance and quality of life. For example: "I provided concentrate to calves because the cow gets bigger and produces more milk" (Man, 46 years), not mentioning any relevance to calves' hunger (DE PAULA VIEIRA et al., 2008); "Good quality calves will result in earlier and more productive cows" (Man, 45). Interestingly, these relationships have scientific support (KHAN et al., 2011; SOBERON \& AMBURGH, 2013), suggesting that some farmers had some understanding of these issues, but that they considered effects on production, not on animal welfare specifically.

Some factors intrinsic (self-responsibility and economic ambition) and extrinsic to farmers (technical assistance, family succession, out of farm experiences, specialization and family commitment) appeared to influence their perceptions, attitudes and choices towards calf rearing practices. Many interviews suggested that farmers positively influenced by these factors tended to adopt rearing practices more favorable for calves' performance and welfare. The analysis of these factors help us to understand the farmers' perceptions, attitudes and choices about the calf breeding practices adopted.

Eighteen $(72 \%)$ participants discussed factors external to the farm, over which they have little or no power to interfere, as more determinant for the performance of the calf rearing system, than internal factors, over which they do have responsibility. Taxes and subsidies are examples of external factors, and calf 'nutrition and health are examples of internal factors. For example: "Our calves lack good genetics; if the 
city council subsidized it, we would use better semen" (Man, 45). Some participants blamed the difficulties involved in calf rearing primarily on factors external to the farm, e.g., "Government doesn't help, so we have no money... If they paid more for the milk I could invest more in the calves..." Man, 53). These views suggested a difficulty of some farmers to perceive the consequences of their own attitudes and choices on the performance of calves. They did not attend calves' births, raised the calves on improvised stalls, and kept bulls on the farm.

In contrast, $13(52 \%)$ farmers showed marked economic ambition, e.g., "I invest in the calves... I use good semen, I feed them hay and concentrates... I want to have a strong cow that produces lots of milk" (Man 65). For some, this seemed to have acted as a propellant of actions on the calves' rearing system, e.g., "We make constant genetic improvement... if the calf is in poor conditions she won't be a good cow... we want a cow of $35 \mathrm{~L} / \mathrm{d}$, and total production above 1,000 $L / d$ ', (Man, 59). These participants declared that they supervise the farm work closely and intend to invest in the dairy business e.g.; "I intend to have top calves and top cows, (Man, 23); "Today I have 25 lactating cows, I intend to reach 45 and produce 1,000 L/day", (Man, 65). Expressions of entrepreneurship appeared associated with the perception of causality between management strategies and calves' performance: "If the calf does not grow properly she will not become a good dairy cow... without concentrate and hay the calves' stomach does not develop... We have made constant genetic improvement" (Man, 59). Since ambition is generally related to pioneering, dynamism and strategic vision (CIRCLE RESEARCH, 2014), the difficulty of some interviewees in perceiving the influence of management practice on calves' performance may be due to a lack of economic ambition.

Some farmers recognized the importance of technical assistance for their activity: "Industry professionals are good, we always try to ask them for information because they know the subject" (Man, 23); "We started with crossbred animals, we used bulls, and today we try to use semen that improves something in the cow; we have evolved thanks to technical assistance" (Man, 28). Participants that received technical assistance tended to have more positive attitudes towards calf rearing (e.g., "We learned from the advisors that calves raised on the farm are adapted and calves from outside can bring disease" (Man, 42), as well as better understanding of the objectives and consequences of the rearing practices proposed (e.g., "I was told by the advisor that colostrum is the main thing, that we must milk the cow immediately after the birth and give the calf colostrum. After I started doing this, it seems that the calves come much better" (Man, 65). This supports other studies that have also shown technical assistance can influence farmers' perceptions and attitudes and promote positive change (KRISTENSEN \& ENEVOLDSEN, 2008; VAARST \& SØRENSEN, 2009; CARDOSO et al., 2016b).

Fourteen participants $(56 \%)$ did not believe that they would have a successor to keep managing their farm. The lack of a successor seems to have led some farmers to perceive dairy farming as ephemeral or secondary. Farmers without successors seemed to have more negative perceptions towards calf rearing practices, perceiving increased labor or lack of return (e.g., "I will not invest much in raising calves because I don't know who will keep the farm running..., Man, 52; "I do not know until when I will produce milk: one son will study, the other is leaving", Man, 49). This prospect seemed to reduce farmers' willingness to invest in training, genetics or infrastructure (e.g., "I will not invest because my son will hardly succeed me”, Man, 53).

In contrast, members of committed families openly recognized the importance of each family member in the business, and in the task of rearing the calves; e.g. "When my wife gets up several times during the night to follow the birth, I feel compelled to share this task with her", (Man, 51). They also showed motivation, and positive attitudes and behaviors towards calf rearing; "We rear the calves well because they all help... calves are in individual stalls..., we feed milk in the bottle... This is done by my daughters" (Man, 43). These type of relationships have been also identified in US dairy family farmers (CABRERA et al., 2009).

Farmers that had had the opportunity to know other cultures and distinct realities, especially urban, appeared to have broadened their perceptions regarding calf breeding systems. Some seemed to recognize this: "Those who have always lived in the same place have resistance to change; when we go out a little, study, see different people, we change our mentality and understand better the importance of calves" (Woman, 41). Similarly, originally urban households that established as farmers in rural France are thought to have contributed significantly to rural and agricultural development (CAZELLA, 2001). Possible reasons for this are that in urban enterprises there are strict schedules, employees are constantly trained and exchange experiences more often than in rural areas. Professionalization also seemed to positively influence farmers' perceptions and attitudes regarding calf rearing.

Given that the perceptions and attitudes of the interviewees may have a considerable impact on calves' 
performance and welfare indicators, these personal characteristics identified in our study may be considered when discussing with farmers changes in calf rearing practices. These findings add to others studies that show that farmers' socio-psychological features are a basic component of the milk production system (BIGRASPOULIN et al., 1985). Adoption of science-based calf rearing techniques and systems seems to require changes in farmers' perceptions and attitudes.

\section{CONCLUSION}

Many calf rearing practices used in the farms participating in this study represent potential risk factors for reduced performance, survival, and animal welfare. Perceptions, attitudes and choices regarding management strategies appeared to be influenced by intrinsic and extrinsic factors to farmers. Selfresponsible, well-informed farmers with urban or out-offarm work experiences, those who specialized in dairy production, that were motivated by family cohesion, had a potential successor or showed economic ambition seemed to invest more and be more concerned with calves' rearing and performance. However, in general farmers did not perceive the welfare of the calves as relevant, and seemed to guide their choices motivated by practical and economic goals, and did not prioritize calf rearing among other farm goals.

\section{ACKNOWLEDGEMENTS}

We thank the Universidade Federal de Santa Catarina (UFSC), Associação Riograndense de Empreendimentos de Assistência Técnica e Extensão Rural (Emater), Emater's technicians and the farmers who participated in the interviews. Maria J. Hötzel acknowledges the support through the Conselho Nacional de Desenvolvimento Científico e Tecnológico (CNPq) PQ grant (P. 311509/20150)) and Gabriela Olmos the Science Without Borders Program for the PDJ Grant (P. 150141/2015-7).

\section{BIOETHICS AND BIOSSECURITY COMMITTE APPROVAL}

This study was approved by the Ethics Committee for Research with Human Beings (protocol 1.344.025) and by the Ethics Committee for the Use of Animals of the Universidade Federal de Santa Catarina (protocol PP00962). Prior to the start of the interviews, each participant was informed that their identity would remain anonymous and provided consent.

\section{REFERENCES}

BALCÃO, L. F. et al. Characterisation of smallholding dairy farms in southern Brazil. Animal Production Science, 57 (4) 735-745, 2017. Available from: <http://dx.doi.org/10.1071/AN15133>. Accessed: Jan. 4, 2017. doi: 10.1071/AN15133.
BIGRAS-POULIN, M. et al. Attitudes, management practices, and herd performance - a study of ontario dairy farm managers. II. Associations. Preventive Veterinary Medicine, 1985. v. 3, n. 3, p. 241-250. Available from: $\quad<$ https://doi.org/10.1016/0167-5877(85)90019-4>. Accessed: Sep. 2, 2016. doi: 10.1016/0167-5877(85)90019-4.

CABRERA, V. E. et al. Studying the impacto of managerial activities on the tecnical efficiency of wisconsin dairy farm. Oviedo, Spain: Economic Discussion Papers, 2009. v. 01/2009. Available from: <http://www.unioviedo.es/oeg/ESP/esp_2009_01. pdf $>$. Accessed: Oct. 10, 2016.

CARDOSO, C. S. et al. Imagining the ideal dairy farm. J Dairy Sci, 2016. v. 99, p. 1663-1671. Available from: <http://dx.doi. org/10.3168/jds.2015-9925>. Accessed: Jan. 10, 2017. doi: $10.3168 /$ jds.2015-9925.

CARDOSO, C. S. et al. Trading off animal welfare and production goals: Brazilian dairy farmers' perspectives on calf dehorning. Livestock Science, 2016. v. 187, p. 102-108. Available from: $<$ http://dx.doi.org/10.1016/j.livsci.2016.02.010>. Accessed: Fev. 16, 2017. doi: 10.1016/j.livsci.2016.02.010.

CAZELLA, A. A. Les installations agricoles nouvelles: le cas des agriculteurs néo-ruraux dans l'Aude (France). France: Espace, populations, sociétés, 2001-1-2. Repopulation et mobilités rurales., 2001. v. 19, n. 1, p. 101-108. Available from: $<$ http://www. persee.fr/docAsPDF/espos_0755-7809_2001_num_19_1_1979. pdf>. Accessed: Aug. 20, 2016. doi: 10.3406/espos.2001.1979.

CIRCLERESEARCH.Ambição. Por que éimportante ser ambicioso e como as PMEs estão alcançando suas metas. Circle Research Agency. The B2B Expertes, England, 2014. Available from: $<$ https://www.sap.com/brazil/docs/download/2015/03/1e378cc5407c-0010-82c7-eda71af511fa.pdf>. Accessed: Aug, 18, 2016.

CORBIN, J.; STRAUSS, A. Basics of Qualitative Research. Techniques and Procedures for Developing Grounded Theory. $4^{\mathrm{a}}$ ed. California: SAGE Publications, Inc, 2015.

COSTA, J. H. C. et al. Invited review: Effects of group housing of dairy calves on behavior, cognition, performance, and health. Journal of Dairy Science, 2016. v. 99, n. 4, p. 2453-67. Available from: <http://dx.doi.org/10.3168/jds.2015-10144>. Accessed: Oct. 24, 2016. doi: $10.3168 /$ jds.2015-10144.

EAGLY, A. H.; CHAIKEN, S. The psychology of atitudes. Fort Worth, TX: Harcourt, Brace, \& Janovich, 1993, 794 pp. Reviewed by Christopher Leone, University of North Florida. Psychol. Mark., 12: 459-466.

ELLIS, K. A. et al. Public opinion on UK milk marketing and welfare. Anim. Welf., 2009. v. 18, p. 267-282. Available from: <http:// www.journalofdairyscience.org/article/S0022-0302(17)30193-5/ references $>$. Aug. 17, 2017. doi: 10.3168/jds.2016-11933.

FISHBEIN, M.; AJZEN, I. Attitudes and Opinions. Annual Review of Psychology, 1972. v. 23, p. 487-544. Available from: <http://www. annualreviews.org/doi/abs/10.1146/annurev.ps.23.020172.002415>. Aug. 17, 2017. doi: 10.1146/annurev.ps.23.020172.002415.

HÖTZEL, M. J.; LONGO, C.; et al. A survey of management practices that influence performance and welfare of dairy calves reared in southern Brazil. PLoS ONE, 2014. v. 9, n. 12, p. 1-17. Available from: <https://doi.org/10.1371/journal.pone.0114995>. Accessed: Dec. 9, 2016. doi: 10.1371/journal.pone.0114995. 
HÖTZEL et al. Bem-estar animal e a produção leiteira. In: SILVA, J. C. P. M. Da et al. (Eds.). Manejo e Administração na Bovinocultura Leiteira. Viçosa: Universidade do Leite, 2014, p. 367-390.

HÖTZEL et al. Citizens' views on the practices of zero-grazing and cow-calf separation in the dairy industry: Does providing information increase acceptability? Journal of Dairy Science, v. 100, n. 5, p. 4150-4160. Available from: <https://doi.org/10.3168/jds.201611933>. Accessed: Mar. 1, 2017. doi: 10.3168/jds.2016-11933.

KHAN, M. A. et al. Invited review: effects of milk ration on solid feed intake, weaning, and performance in dairy heifers. United States: Journal of Dairy Science, Mar. 2011. v. 94, n. 3, p. 1071-1081 Available f rom: < http://dx.doi.org/10.3168/jds.2010-3733>. Accessed: Aug. 30, 2016. doi: 10.3168/jds.2010-3733.

KRISTENSEN, E.; ENEVOLDSEN, C. A mixed methods inquiry: How dairy farmers perceive the value(s) of their involvement in an intensive dairy herd health management program. Acta Veterinaria Scandinavica, 18 Dec. 2008. v. 50, n. 1, p. 50. Available from: $<$ https://doi.org/10.1186/1751-0147-50-50>. Accessed: Jul. 18, 2016. doi: 10.1186/1751-0147-50-50.

MATURANA, H. O que é ver? In: MAGRO, C. et al. (Eds.). A ontologia da realidade. $3^{\text {a }}$ reimpre ed. Belo Horizonte: UFMG, 2002, p. $77-105$.

MINAYO, M. C. De S. O desafio do conhecimento: pesquisa qualitativa em saúde. 13. ed. São Paulo: Hucitec, 2013.

PAULA VIEIRA, A. DE et al. Behavioural indicators of hunger in dairy calves. Applied Animal Behaviour Science, 2008. v. 109, n. $2-4$, p. $180-189$. Available from: <http://dx.doi.org/10.1016/j. applanim.2007.03.006>. Accessed: Jun. 8, 2016. doi: 10.1016/j. applanim.2007.03.006.

SANTOS, G. DOS; BITTAR, C. M. M. A survey of dairy calf management practices in some producing regions in Brazil. Revista
Brasileira de Zootecnia, 2015. v. 44, n. 10, p. 361-370. Available from: $<\mathrm{http} / /$ dx.doi.org/10.1590/S1806-92902015001000004>. Accessed: May 12, 2016. doi: 10.1590/S1806-92902015001000004.

SENGE, P. M. The Fifth Discipline: The Art \& Practice of The Learning Organization. New York: Crown Publishing Group, 2010. 464p.

SOBERON, F.; AMBURGH, M. E. VAN. The effect of nutrient intake from milk or milk replacer of preweaned dairy calves on lactation milk yield as adults: A meta-analysis of current data. Journal of Animal Science, 2013. v. 91, n. 2, p. 706-712. Available from: <http://dx.doi.org/10.2527/jas.2012-5834>. Accessed: Jun. 28, 2016. doi:10.2527/jas.2012-5834.

TORSEIN, M. et al. Associations between calf mortality during days 1 to 90 and herd-level cow and production variables in large Swedish dairy herds. Journal of Dairy Science, 2014. v. 97, n. 10, p. 6613-21. Available from: <https://doi.org/10.3168/jds.20147949>. Accessed: Mar. 14, 2016. doi: 10.3168/jds.2014-7949.

VAARST, M.; SØRENSEN, J. T. Danish dairy farmers' perceptions and attitudes related to calf-management in situations of high versus no calf mortality. Preventive Veterinary Medicine, 1 May. 2009. v. 89, n. 1-2, p. 128-133. Available from: <https://doi.org/10.1016/j. prevetmed.2009.02.015>. Accessed: May 20, 2016.

VON KEYSERLINGK, M. A. G. et al. Invited review: The welfare of dairy cattle--key concepts and the role of science. Journal of Dairy Science, 2009. v. 92, n. 9, p. 4101-11. Available from: <https://doi. org/10.3168/jds.2009-2326>. Accessed: Nov. 22, 2016. doi: 10.3168/ jds.2009-2326.

VON KEYSERLINGK, M. A. G.; HÖTZEL, M. J. The Ticking Clock: Addressing Farm Animal Welfare in Emerging Countries. Journal of Agricultural and Environmental Ethics, 2015. v. 28, n. 1, p. 179195. Available from: $<\mathrm{http}: / / \mathrm{dx}$.doi.org/10.1007/s10806-014-9518-7>. Accessed: Sep. 24, 2016. doi: 10.1007/s10806-014-9518-7. 